\title{
Financial constraints and the decision to lease - Evidence from German SME
}

\author{
Constantin F. Slotty*,** \\ Goethe University Frankfurt, House of Finance, Germany
}

July 2009

\begin{abstract}
The objective of this paper is to test the hypothesis that in particular financially constrained firms lease a higher share of their assets to mitigate problems of asymmetric information. The assumptions are tested under a GMM framework which simultaneously controls for endogeneity problems and firms' fixed effects. We find that the share of total annual lease expenses attributable to either finance or operating leases is considerably higher for financially strained as well as for small and fast-growing firms - those likely to face higher agency-cost premiums on marginal financing. Furthermore, our results confirm the substitution of leasing and debt financing for lessee firms. However, we find no evidence that firms use leasing as an instrument to reduce their tax burdens.
\end{abstract}

Keywords: Leasing; financial constraints; capital structure; asymmetric information JEL Codes: D23, D92, C23

\footnotetext{
${ }^{\ddagger}$ This research paper is part of a project funded by the German Savings Bank Association. The expressed opinions are strictly those of the author and do not necessarily reflect those of the affiliated organizations.

${ }^{*}$ Constantin F. Slotty, Goethe University Frankfurt, Chair of International Banking and Finance, House of Finance, Grüneburgplatz 1, 60323 Frankfurt am Main, Germany, Phone: +49(0)69 798-33670, e-mail: slotty@finance.uni-frankfurt.de

${ }^{* *}$ I thank Christian Laux, Jan Pieter Krahnen, Nicolaus Newiger, Christian Schlag, Marcel Tyrell, the participants of the brown bag seminar series, and seminar participants at the 2009 Midwest and Southwestern Finance Association Meetings for helpful comments. The usual disclaimer applies.
} 


\section{Introduction}

The determinants which drive firms' capital structure decisions have been at the heart of corporate finance research. Almost 20 years ago Harris and Raviv (1991) concluded that research on theoretical models explaining capital structure decisions under asymmetric information has reached a point of diminishing returns. However, up to date there has been a wide gap between empirical evidence on this topic and its theoretical counterpart (Hackethal and Schmidt 2004). Bharath et al. (2006) find for a sample of U.S. firms that information asymmetry does affect capital structure decisions but do not consider lease financing. We aim to fill this void by investigating whether firms for which information asymmetries are more severe lease a greater share of their assets by considering a group of firms that is particularly affected: Small and medium sized enterprises (SME).

The financial intermediation literature offers several hypotheses about which intermediaries have vantages in providing financing to small and informationally opaque firms. An often suggested remedy to mitigate the effects of asymmetric information which can cause credit rationing is relationship lending where banks not only seize quantitative but also qualitative (so-called soft-) information about their clients (e.g. Petersen and Rajan (1994)). However, the introduction of the Basel II accord and the associated risk-adjusted pricing of loans has set limits to this form of financing and made credit for companies with poor ratings more expensive or in other cases led to rationing (KfW 2008). To this end, leasing can represent a valuable alternative.

So far, academic research on leasing mainly focused on tax-arbitrage and the question whether leases and debt serve as substitutes or complements. Contrary to economic theory Ang and Peterson (1984) found a complementing relation between debt and leases. This finding was later re-examined by Adedeji and Stapleton (1996) who found evidence in favor of the substitution theory and suggested that the positive relationship reported by Ang and Peterson was induced by the inclusion of a large number of non-leasing companies as well as a lack of controlling for taxable capacity. In the same vein, Yan (2006) and Deloof et al.'s (2007) results yielded evidence that leases and debt substitute each other empirically rather than acting as complements.

This paper contributes to the existing literature on leasing by shifting the debate to the question under what conditions leasing can serve as an alternative form of finance when firms are financially constrained. Theory suggests that the lessors ability to repossess the asset enables him 
to grant more credit than a lender who takes a security interest in an asset - a feature which becomes particularly relevant in the presence of financing constraints. Eisfeld and Rampini (2009) point out that this property has implications on several key aspects of corporate finance and suggest that the amount of operating leases may be used as a revealed preference indicator of the extent to which a firm is financially constrained. If that hypothesis were correct we should expect to see firms which are more likely to be financially constraint - due to asymmetric information or higher risk - to employ more lease financing. However, a well-known problem among empiricists in this field is to actually find a good proxy for the degree of firms' financial constraint. We attempt to tackle this problem by considering a range of indicators associated with financing constraints and argue that a significance of several of these factors would yield strong circumstantial evidence to support this hypothesis. Thus we look in particular at small, fast-growing, liquidity strained companies as well as firms with lower sales margins to assess whether such firms have a greater propensity to lease.

This paper employs a unique panel data set with detailed financial information on 20,442 small and private German firms over the period 2002 - 2006 which has been provided by the German Savings Banks Association (DSGV). To test our hypotheses we apply a generalized method of moments (GMM) framework which simultaneously controls for endogeneity problems and firms' fixed effects. To account for differences in the reporting requirements for leases in Germany in comparison to US Financial Accounting Standards (FAS 13) we follow Beattie et al. (2000) and consider a comprehensive measure of leasing which includes total lease expenses (i.e. operating and finance) from the profit and loss statements instead of capitalized leases from balance sheet data. ${ }^{1}$

By way of preview, our most important findings are as follows: (i) SME which lease a larger fraction of their assets are characterized by smaller size, fast-growth, higher interest rates, strained liquidity and lower sales margins; (ii) around half of the firms in our sample make use of leasing of which $90 \%$ prefer non-capitalized leases; (iii) the use of leasing as financing instrument has increased by $16 \%$ (in relative terms) over the observation period. However, it seems to be much more important for smaller firms for which leases represent the major part (52\%) of their external financing costs; (iv) leases and debt are found to be used as substitutes. This is implied by the negative sign of the coefficient for debt and the positive sign of the interest

\footnotetext{
${ }^{1}$ The reporting requirements for leases in Germany differ from requirements in the US. Contrary to FAS 13 there are capitalized and non-capitalized finance leases depending on the specific nature of the contract. Thus a finance lease is not distinguishable from an operating lease if it is not capitalized on the lessee's balance sheet.
} 
rate coefficient (both significant); (v) we find no evidence that firms use leases to reduce their tax burden. In fact, our analysis shows that firms with lower tax expenses (before financing costs) have a greater tendency to lease. As a final contribution, this paper shows that estimation results are biased if problems of endogeneity and heteroskedasticity are not accounted for.

An overview over the importance of leasing in Germany and the regulatory framework is given in section 2. In section 3, a brief outline of the theoretical notion of rationales for firms to lease is provided and the hypotheses for the instated variables are discussed. Section 4 describes the data characteristics and presents several descriptive statistics. Section 5 provides the methodology. The results of the econometric models are presented in section 6 and section 7 summarizes and concludes.

\section{Leasing in Germany}

Leasing history in Germany began in 1962 with the foundation of the first leasing company, ten years after the origination of its first counterpart in the United States. Since then, leasing has encountered a steadily increasing importance as an investment alternative. According to the Association of German Leasing Companies (Bundesverband Deutscher Leasing-Unternehmen), in 2007 leasing companies financed investments of $€ 57.4$ billion of which $88 \%$ was accountable to movable investment goods. This was close to $10 \%$ more than in 2006 and set a new record. By the end of 2007, leasing accounted for $18 \%$ of all investments made in Germany.

A recent study for the German leasing market which interviewed 706 lessee firms (TNS Infratest 2007) reported that the top two reasons for firms to lease are the predictability and transparency of costs (59\% of the participants) and a preference for machinery and equipment that is always up-to-date (52\%). The argument that leasing preserves capital was confirmed by $46 \%$ of the participants whereas $42 \%$ stated the tax argument as an important factor to lease. Interestingly, the argument that leasing preserves capital was given as first reason in the corresponding surveys made in 1994 and 2002. A possible explanation for this change in priorities could provide the leap of the economy in the preceding year to the study. This boom was in particular fuelled by strong domestic demand (KfW 2007) which led to a larger financial cushion for German SME and a possible decreased preference (in relation to the other factors stated) for the preservation of capital. 
Accounting and tax requirements for leases According to FAS requirements a finance (capital) lease is capitalized by the lessee and reported as corresponding debt obligation on the balance sheet. Consequently, the lessee depreciates the leased asset and amortizes the debt liability. A finance lease is thus akin to a debt obligation and requires similar disclosures as an asset purchase. An operating lease, on the other hand, represents off-balance-sheet financing for the lessee, and is reported on the profit and loss statements as a lease expense. Under German accounting rules (HGB), however, a finance lease is not automatically capitalized by the lessee but defined by the following procedure: First, a finance lease is constituted if (i) the leasing contract cannot be canceled during its duration and (ii) if the cumulative leasing rates cover at least the purchase and finance cost of the lessor (full-pay-out-lease). ${ }^{2}$ Second, the requirements for the lessee to report the finance lease on the balance sheet are determined by four conditions stated in table $1 .^{3}$

\section{[Insert table 1 around here]}

In summary, operating leases are not reported on the balance sheet whereas finance leases are only capitalized by the lessee if the above stated requirements hold. However, practitioners conveyed to us in discussions that in practice finance lease contracts predominate and are commonly designed for the lessor to depreciate the asset. Thus, by assessing the amount of finance leases by capitalized lease obligations on the balance sheet one must be aware that this number may be understated. Since we can not distinguish an operating lease from a non-capitalized finance lease we refer henceforth to the terms capitalized and non-capitalized lease. ${ }^{4}$

\section{Theoretical framework}

The basic economic rule to buy or lease is rather straightforward: Buy if the equivalent annual cost of ownership and operation is less than the best lease rate offered by a lessor. However, one

\footnotetext{
${ }^{2}$ There is no definition for an operating lease under German law; an operating lease is simply equated with a non-finance lease.

${ }^{3}$ For the corresponding German rulings see "Bundessteuerblatt (1971), page 264, paragraph II".

${ }^{4}$ For tax requirements, the main difference in the two types of leases is that operating leases, unlike finance leases, also provide trade tax advantages (until 2008) because interest payments included in the lease expenses do not affect the taxable base as for instance interest payments on liabilities do. The basis for taxation of leases in Germany is in $\S 39$ General Tax Code as interpreted by the Federal Tax Court (1970). Based on this law the Ministry of Finance decreed four general letter rulings issued in 1971 and 1972 (full-pay-out-leases) and 1975 and 1991 (non-full-pay-out-leases).
} 
of the most prominent features of leasing contracts is their flexibility toward customers needs and thus there is also a non-monetary utility associated with lease financing.

First, cash-flows originating from the asset and pay back rates may be aligned in order retain liquidity. Likewise, many leasing contracts incorporate full maintenance of the leased asset which reduces its operating risk. Second, leasing contracts often contain useful options protecting firms from increases in future lease rates. This option can be a beneficial feature if future asset values or lease rates are uncertain (McConnell and Schallheim 1983). But there are also economical rationales to choose leasing instead of debt financing; a lessor may be able to exploit economies of scale by buying and managing assets in bulk at less expense than the lessee. These economies of scale can also help to overcome the inherent problem of commercialization of the asset after repossession in particular if the asset is firm-specific and/or a market for such an asset is fairly small or inexistent. Another reason is the often mentioned tax advantage: If the tax rate of the lessor exceeds that of the lessee the tax savings from deducting the depreciation of the asset can be split between the two parties or transferred to the lessee in form of smaller leasing payments (e.g. Elayan et al. (2006)).

Adedeji and Stapelton (1996) hypothesize that leasing may be used as a secondary, more expensive form of finance, after firms have used up their primary debt capacity. They illustrate a solution to this apparent contradiction of the lease-debt substitutability theory by the example of the demand for two close substitutes, such as apples and oranges: Consumers who do not like fruits will have a low demand for both whereas consumers which appreciate fruits will have both albeit in a substitutional relation.

Yan (2006) also takes the cost of debt into consideration and interprets rising interest rates paid on outstanding debt with rising leases as evidence of the substitution-theory and argues that this interpretation is in line with the trade off theory of capital structure. This interpretation, however, poses the question of the direction or causality of the relation: Does the use of (extensive) debt foster leasing in the sense that lessors offer capital to financially constrained firms (i.e. firms facing difficulties of obtaining regular credit from a bank) or do the extra amount of leases increase the probability of default and thus increase the cost of external capital? An argument can be made for both perspectives. On the one hand, German insolvency law (§ $47 \mathrm{InsO}$ ) does not count leased assets as bankruptcy assets and thus reduces the loss given default for the lessor in case of a firm insolvency. This enables him to implicitly extend more 
credit than a lender whose claim is secured by the same asset (Eisfeldt and Rampini 2009). ${ }^{5}$ Thus, the ability to repossess an asset allows the lessor to provide financing even to borrowers who are financially constrained due to low degrees of creditworthiness or higher rates of debt.

Another explanation for the incentive of firms to lease could be to limit credit exposure to their house bank(s) to mitigate potential hold-up problems. These leases, however, are treated as additional debt by banks and thus reduce the debt capacity because they raise the probability of default. ${ }^{6}$ Therefore, additional leases also have an impact on the interest rate charged by banks on additional loans provided that banks act rationally. However, if leasing is provided by the same bank, the hold-up problem remains.

A similar notion applies to the leverage of a firm as well as to its ratio of fixed asset to total assets. Clearly, the use of operating leases has an impact on its capital intensity because leased fixed assets are not recorded on the balance sheet. But capital intensive firms may also have a stronger incentive to lease to mitigate the underinvestment problem described by Stulz and Johnson (1985) and for factors such as service contracts for the leasing gods or the optionargument made by McConnell and Schallheim.

These ambiguous relations have implications on the type of the utilized econometric model and will be addressed in section 5 .

\subsection{Hypotheses and instated variables}

In the following, table 2 presents the hypotheses tested in the regressions as well as the economic rationales on their influence. Table 3 consists of three different sets of variables: (i) dependent; (ii) independent (firm characterisitcs); and (iii) control variables. All variables (except legal form) have been deflated by the consumer price index of 2005 .

[Insert table 2 around here]

[Insert table 3 around here]

\footnotetext{
${ }^{5}$ Contrary to German legislature, lessors under the Chapter 11 Bankruptcy Code in the US have a diminished ability to claim the asset once a firm is in default. However, it is possible and likely that US leasing contracts differ from German ones to account for this eventuality.

${ }^{6}$ See e.g. Molina (2005) for the impact of leverage on ratings.
} 


\section{Data and descriptive overview}

Our sample draws on data provided by the German Savings Banks Association (DSGV) and contains 147,376 financial statements of (anonymized) small and medium enterprises for the period 2002 to 2006 . For our descriptive analysis we start by dividing the sample into leasing (62,257 observations) and non-leasing firms (85,119 observations). In the next step the sample of firms which use lease financing is sorted for outliers and firm observations with missing variabes are eliminated. These adjustments lead to the final (unbalanced) sample used in the regressions and comprises 20,442 firm observations. Table 4 starts by giving an overview over the full sample while subsequent tables describe the observations used in the regression analysis.

We see that the proportion of firms which use leasing has increased by $27.5 \%$ in relative terms over the observation period. Notably, firms decreased their overall leverage during this period from $80 \%$ to $72 \%$ accompanied by a decrease of their rates paid on external capital from $5.1 \%$ to $4.3 \%$. A separate inspection of lessee and non-lessee firms yields the interesting observation that lessee firms are higher leveraged. ${ }^{7}$ This finding was also reported by Ang and Petersen (1984) and led to the well-known "leasing puzzle" which was, as mentioned earlier, induced by an inclusion of non-lessee firms in the sample.

\section{[Insert table 4 around here]}

Table 5 now turns to the sample consisting only of lessee firms and looks at the properties of firms using capitalized finance and non-capitalized leases. With a $90 \%$ usage of the latter, non-capitalized leases seem to be the predominant form of leasing in Germany. The decision to capitalize leases seems to be driven in part by lower leverage ratios or factors which simultaneously influence both, like firm size. Large firms, for instance, frequently lease assets such as firm-specific production lines with low secondary market values which, in turn, have to be recorded as capitalized leases.

\section{[Insert table 5 around here]}

To put the importance of leasing in regard to firm size into perspective table 6 describes the financing costs of smaller and larger firms in the sample. ${ }^{8}$ We see that overall lease expenses

\footnotetext{
${ }^{7} \mathrm{~A}$ ratio of $77 \%$ debt to total assets for lessee firms and $70 \%$ for non-lessee firms. A two-sample Wilcoxon rank-sum (Mann-Whitney) test suggests that these differences are not caused by random fluctuation.

${ }^{8}$ Quartile one (smaller firms) includes firms with total assets up to $€ 0.37 \mathrm{~m}$, quartile two up to $€ 1.04 \mathrm{~m}$, quartile three up to $€ 3.37 \mathrm{~m}$ and the fourth quartile (larger firms) contains all firms with total assets greater than $€ 3.37 \mathrm{~m}$. The respective figures monotonically increase (interest) or decrease (leases) from 1st to 4th quartile. However, for illustrating purposes only 1 st and 4th quartile are reported.
} 
have a large impact on firms' external financing costs. This impact is even stronger for smaller companies for which leasing constitutes the major part (52\%) of financing expenses. Large firms, on the other hand, cover a relatively smaller $32 \%$ of their external finance requirements by leases while $68 \%$ stems from debt financing. Moreover, we see that not only the number of firms using leasing has risen (table 4) but also firms' share of external funding costs attributable to leasing increased from $37 \%$ in 2002 to $43 \%$ in 2006. However, although leasing seems to play a large role for SME the impact on firms' overall financing costs is likely to be overstated because lease expenses - opposed to interest expenses - frequently include the depreciation of the financed assets. Since leasing contracts greatly differ in their form and maturity the exact impact is difficult to assess.

\section{[Insert table 6 around here]}

To sum up, around half of the firms in our sample make use of leasing of which $90 \%$ prefer non-capitalized leases. The use of leasing as financing instrument has increased by $16 \%$ (in relative terms) over the observation period while it seems to be much more important for smaller firms for which leases represent the major part of their external financing costs.

\section{Methodology}

To model the relation between a firm's leasing rate and the explanatory variables from section three we start with a common fixed effects linear panel model. ${ }^{9}$ The reason for this approach is to (i) test the robustness of our assumptions under different models and to (ii) assess the potential bias arising from endogeneity and heteroskedasticity problems which are accounted for in later models. Subsequently, we specify the model as follows:

$$
\begin{aligned}
L R_{i t}= & \alpha_{i}+\beta_{1} L E_{i t}+\beta_{2} A C I_{i t}+\beta_{3} C I_{i t}+\beta_{4} T R_{i t}+\beta_{5} S Z_{i t}+\beta_{6} R O A_{i t} \\
& +\beta_{7} L Q_{i t}+\beta_{8} S M_{i t}+\beta_{9} G E_{i t}+\sum_{j=10}^{16} \beta_{j} L F_{i}+\gamma_{t}+\epsilon_{i t}
\end{aligned}
$$

with the respective abbreviations depicted in parentheses: LR (lease ratio), LE (leverage), ACI (average cost of interest), CI (capital intensity), TR (tax rate), SZ (firm size), ROA (profitability), LQ (liquidity), SM (sales margin), GE (growth enterprise) and LF (legal form) with $\mathrm{j}=$ $10, \ldots, 16$.

\footnotetext{
${ }^{9}$ Fixed effects were preferred to random effects based on Hausman testing.
} 
As pointed out in section three there is potential simultaneity in the proposed function which means that for some variables the function works not only in the direction $Y=f(X)$, but also $X=f(Y)$. This two-way causality can lead to a correlation of the explanatory variables with the error term which leads to a failure of the zero conditional mean assumption $E\left(u_{i} \mid x_{i}\right)=0$. This failure of the i.i.d condition will yield inconsistent estimates of any regressions with OLS methods, however specified, where reverse causality might be present.

This notion that two or more variables are jointly determined in the behavioral model is stated as a problem of endogeneity. In order to cope with the problem of endogeneity in simultaneous systems instrumental variable (IV) measures were developed. The basic idea of IV measures is to isolate the two parts of the explanatory variable (x): The part correlated with $\epsilon$ and the part uncorrelated with $\epsilon$. By identifying an IV (z) that is correlated with $\mathrm{x}$ but not with $\epsilon, \beta_{i}$ can be estimated consistently. The requirements for the IV are thus (i) relevance: $\operatorname{cov}\left(z_{i}, x_{i}\right) \neq 0$ and (ii) exogeneity: $\operatorname{cov}\left(z_{i}, \epsilon_{i}\right)=0$. We follow the frequently applied approach in econometrics of overcoming the problem of finding appropriate IVs by instrumenting the endogenous variables using exogenous variables and lags of the endogenous variables as instruments.

This paper defines the setting for the IV estimation as a generalized method of moments (GMM) optimization problem as introduced by Hansen (1982). The advantages of GMM over IV are that in the presence of heteroskedasticity the GMM estimator is more efficient than the simple IV estimator, whereas if heteroskedasticity is not present, the GMM estimator is no worse asymptotically than the IV estimator (Baum, Schaffer, and Stillman 2003). An analytical deduction of both the IV and GMM estimation framework is also provided by Baum and Schaffer (2007). For the two-step GMM estimation we utilize model (2) with the variables $L E_{i t}, A C I_{i t}$ and $C I_{i t}$ considered endogenous. The variables are so instrumented by the exogenous variables: $T R_{i t}, S Z_{i t}, R O A_{i t}, L Q_{i t}, S M_{i t}, G E_{i t}, L F_{i}, \gamma_{t}$; and the previous realizations of the endogenous variables : $L E_{i t-1}, L E_{i t-2}, A C I_{i t-1}, A C I_{i t-2}, C I_{i t-1}$ and $C I_{i t-2}$. All the regressions are estimated using Schaffer's (2005) xtivreg2-procedure in STATA.

To account for heteroskedasticity of unknown form robust standard errors are computed to derive a consistent estimate of the variance-covariance matrix (VCE). Furthermore, the model presented in table 9 (results section) also accounts for autocorrelation in the disturbance terms by computing Newey-West (1987) estimates of the VCE using the Bartlett-kernel weighting (Baum 2006, p.199). 


\section{Results}

To obtain a first impression about the magnitude and direction of the relation between the variables the correlation matrix is presented in table 7 . The results of the matrix should be interpreted with caution because pair-wise correlation can be misleading if control factors are omitted that are simultaneously correlated with both variables.

\section{[Insert table 7 around here]}

The matrix shows in particular, that long-term debt has negative impact on the leases whereas short term debt positively influences the lease ratio. Hart and Moore (1995) suggest that total long-term financing should roughly equal total long-term investments because long-term asset tend to be financed with long-term liabilities. Thus, the observed relation could indicate that firms which are restrained from long-term financing fund their growth with leasing and shortterm debt. The amount of trade credit, on the other hand, is often applied in academic literature as a proxy for the financial constraint of a firm (Petersen and Rajan 1995). The implicit assumption is that the rates for trade credit are frequently much higher than for funds obtained from banks (Smith 1992). Thus, the positive sign of trade credit could imply that financially constrained firms lease more. This notion is implemented in table 8 (model 1) which shows the results of the fixed effects panel estimation when total debt is divided into trade credit, short-term and long-term debt. All regressions are run with both time fixed effects and dummy variables accounting for the legal form of the respective firm.

\section{[Insert table 8 around here]}

The results for model (1) show that the coefficients for trade credit, short-term credit and long-term credit are all negative while only long-term credit is significant at the $10 \%$ level. In regard to trade credit, Miwa and Ramseyer (2005) point out that evidence for trade credit as expensive form of external financing is weak and also difficult to reconcile due to its ubiquitous nature. Since the various debt maturities have the same directional influence on the lease ratio subsequent models comprise the different debt maturities to a single measure for total debt obligations.

The results for model (2) show that the coefficient for leverage is insignificant when the model is estimated with a robust sandwich estimator. Notably, the average cost of debt are also not significant in either model. The coefficients for capital intensity, firm size and the tax rate, 
on the other hand, are in line with expectations. However, a model check in form of a modified (for unbalanced data) Wald test for groupwise heteroskedasticity (Greene 2000, p. 598) in the fixed effect regression models rejects the null hypothesis of homoskedastic errors in the context of pooled cross-section panel data at the 1\% level. Although Baum (2000) notes that in the context of fixed effects with "large $\mathrm{N}$ and small $\mathrm{T}$ " panel simulations of the test statistic have shown that its power is very low, we can not discard the presence of heteroskedasticity and thus the probability that the standard errors of our coefficients are underestimated. The second problem, as addressed in the previous section, is that the estimations are likely to suffer from a bias due to endogeneity problems.

Therefore, we now turn to the final model (table 9) which accounts for potential endogeneity problems as well as for firms' fixed effects. Because a Wooldridge test (Wooldridge 2002, p. 264) for autocorrelation in panel data rejects the null of no first-order autocorrelation the model uses standard errors that are robust for heteroskedasticity and autocorrelation. ${ }^{10}$ Due to the instrumenting of our three endogenous variables, however, about half of the observations are lost.

\section{[Insert table 9 around here]}

First, we take a look at the variables that are likely to reflect some kind of credit constraint. Myers (1976) suggested that growth firms will employ less debt finance because of possible agency problems. Based on this notion, Stulz and Johnson (1985) show that a firm and its creditors can mitigate the underinvestment problem by allowing subsequent debt to be secured by the financed assets. Hence, leasing contracts with the inherent ability of the lessor to repossess the asset can offer finance to firms that are at the limit of their debt capacity. The regression results show that the relation between the growth rate of firms and leasing is positive and significant at the 5\% level suggesting that high-growth firms tend to lease assets to overcome the underinvestment problem. Even though this effect is statistically significant, the small value of its coefficient suggests that its economic impact is rather small. Similarly, the lower sales margins of lessee firms ( $1 \%$ level) show that these firms either have commodity products and/or a low cost efficiency which, in turn, could indicate a lower debt capacity. Although low sales

\footnotetext{
${ }^{10}$ The model presented in table 9 was also estimated with the ratio of finance lease obligations over total assets as dependent variable (not reported). Yet, all variables turned out insignificant and the weak identification test suggested a severe bias. This is in line with the findings of Sharpe and Nguyen (1995) and supports the idea that it is the lower cost of repossessing capital under operating leases which causes the empirical relationship between financial characteristics and the fraction of leased capital.
} 
margins and profitability do not automaticially rule each other out (e.g. telecom companies frequently exhibit these properties) the relatively small size of the firms in our sample does not seem to support such business models. The negative relation between liquidity and leasing (5\% level), on the other hand, could imply credit rationing by banks due to a higher probability of default because companies can not ensure to pay back their short-term debt by the liquidation of short-term assets within a given time frame. Further, the firm size coefficient is also negative and highly significant (at the 1\% level) indicating that smaller firms may lease a greater share of their assets due to asymmetric information problems. Because our sample is rather homogeneous (in terms of firm size) it would be conceivable that the differences in size are too small to have an impact on the degree of the informational transparency of the firms. However, if we consider the legal form of firms we see that in particular those legal forms which are predominatly used by small firms with no or very limited disclosure requirements (Einzelfirma, BGB-Gesellschaft, KG, OHG) have positive and significant coefficients. The legal form coefficient, on the other hand, that is primarily used by larger firms (AG) with stricter disclosure rules has a negative sign. ${ }^{11}$ These findings provide further suggestive evidence supporting the theory that smaller firms tend to be more opaque than larger firms, even in relatively homogeneous samples such as the one employed.

Secondly, the negative sign of the leverage and the positive sign of the average interest cost coefficient (both significant) are in line with the substitution theory of leases and debt and indicate that firms with higher funding costs lease a larger proportion of their assets. The coefficient for profitability (ROA) is positive and significant at the 5\% level which is likely to reflect the mechanical relation that the ROA rises when its denominator is decreased by the use of more leases. A similar explanation is suggested in case of the capital intensity whose negative and significant ( $1 \%$ level) coefficient seems to support the notion that firms with a higher share of leases record less assets on their balance sheet. Lastly, firms seem not to use leases to reduce their tax burden. In fact, we observe the opposite: firms with lower tax expenses employ more lease financing. This finding casts some doubt on the often made argument by lessors that leasing helps to "save" taxes.

\footnotetext{
${ }^{11}$ We refrain here from translating the respective legal forms in English because there are no exact legal equivalents in the US or UK, in particular in regard to the disclosure requirements.
} 
Model validation tests We start the assessment of the robustness of our results by considering the underidentification test. ${ }^{12}$ The underidentification test is a Lagrange multiplier (LM) test of whether the excluded instruments (in this case the lagged variables) are relevant, i.e. correlated with the endogenous regressors. The test is basically the test of the rank of a matrix: under the null hypothesis that the equation is underidentified, the matrix of reduced-form coefficients of the excluded instruments $(L 1)$ has $\operatorname{rank}=K 1-1$ where $K 1=$ number of endogenous regressors. Under the null, the statistic is distributed as $\chi^{2}$ with $(L 1-K 1+1)=$ degrees of freedom (Baum, Schaffer, and Stillman 2007). The rejection of the null for our model (table 9) indicates that the matrix is full column rank, i.e. that our model is identified.

Now that we know that our IVs are correlated with the endogenous variables we also need to check whether they satisfy the second requirement of $\operatorname{cov}\left(z_{i}, \epsilon_{i}\right)=0$. This is done with a the Sargan-Hansen test of overidentifying restrictions (Hansen 1982). In a GMM framework this test becomes Hansen's J statistic which is consistent in the presence of heteroskedasticity and autocorrelation. The joint null hypothesis is that the instruments are uncorrelated with the error term, and that the excluded instruments are correctly excluded from the estimated equation. A rejection of the test statistic would cast doubt on the validity of the instruments. In our case, however, the statistic is far from the rejection of its null, giving us greater confidence that the set of instruments is appropriate.

Subsequently, we test for weak identification which arises when the excluded instruments are only weakly correlated with the endogenous regressors. If the excluded instruments have only little explanatory power an increased bias in the estimated IV coefficients will be the consequence and the estimates may thus be no improvement over OLS.

Stock and Yogo (2005) provide testing for weak instruments with the null that instruments are weak. Weak instruments can lead to an asymptotic maximal IV relative bias (relative to the bias of OLS) that it is subject to some critical level which the investigator finds unacceptably large. In respect to the estimated model the weak instrument bias is less than $15 \%$ of OLS which we interpret as acceptably small. ${ }^{13}$

If we compare the results of table 8 for fixed effects models and table 9 for GMM models it shows that in particular the impact of the variables that most likely encounter problems of endogeneity (leverage and interest costs) is severely underestimated if endogeneity is not accounted for. As Yan (2006) points out, this identification problem may be the explanation to the

\footnotetext{
${ }^{12}$ Values for all discussed robustness checks are reported in table 9.

${ }^{13}$ For a further discussion of weak instrument testing for linear models see Stock and Yogo (2005).
} 
controversy of findings of previous studies that examined debt-lease relationships.

\section{Conclusion}

The objective of this paper has been to present and discuss empirical evidence on the role of leasing for small and medium sized enterprises. Over the examined period the number of firms using leasing (operating and finance) has grown by $27.5 \%$. Altogether around $50 \%$ of firms in our sample used some form of leasing at the end of 2006 of which $90 \%$ preferred non-capitalized leases. But not only prevalence but also the use of leases for lessee firms has increased by $16 \%$ over the observation period.

We tested in particular the hypothesis that financially constrained firms lease a higher share of their assets to mitigate problems of asymmetric information. Therefore, a comprehensive measure of total lease expenses was utilized as proxy for the degree of the financial constraint of a firm.

For small firms leasing appears to play a vital role in providing financing, since leasing costs comprise $52 \%$ of their external financing expenses. Larger firms, on the other hand, cover a relatively smaller $32 \%$ of their external financing requirements with leasing. Notably, the average interest costs are $5.1 \%$ for small firms and $4.2 \%$ for larger SME in our sample. These descriptive figures are further corroborated by the results of a GMM estimation that higher interest costs, smaller firm size, strained liquidity and higher growth rates have a positive impact on leasing.

On balance the descriptive and empirical evidence seems to support the theory that firms which are more likely to suffer from problems of asymmetric information have a greater exigency to lease. These results are in line with Sharpe and Nguyen (1995) who find strong support for the hypothesis that firms that are prone to be burdened with relatively high premiums for external funds also have a greater propensity to lease as well as with the findings of Krishnan and Moyer (1994) that lessee firms have higher growth rates. Furthermore, the results suggest that the tax argument, often used by lessors as selling point, does not have an impact on the decision to lease.

Another important facet of leasing that has, to our knowledge, not been covered by academic research so far are the principal-agency problems in joint ventures between lessors and banks that can arise if banks - on the basis of commission or on their own account - also offer leasing 
to their customers. This other side of the principal-agent relationship we suggest, provides an interesting field for further research. 


\section{Tables}

\section{Table 1: Requirements for the lessee to capitalize the finance lease}

\begin{tabular}{|c|c|c|c|}
\hline $\begin{array}{l}\text { Lease without option to } \\
\text { buy or prolong }\end{array}$ & $\begin{array}{l}\text { Lease with option to buy } \\
\text { the asset }\end{array}$ & $\begin{array}{l}\text { Lease with the option to } \\
\text { prolong the contract }\end{array}$ & Special lease \\
\hline $\begin{array}{l}\text { (a) If the minimum lease } \\
\text { term is less than } 40 \% \text { or } \\
\text { more than } 90 \% \text { of the aver- } \\
\text { age useful life of the asset }\end{array}$ & $\begin{array}{l}\text { (a) or (b) if the minimum } \\
\text { lease term is less than } 40 \% \\
\text { or more than } 90 \% \text { of the } \\
\text { average useful life of the } \\
\text { asset and if the option } \\
\text { price to buy the asset is } \\
\text { less than its value resulting } \\
\text { from a linear depreciation } \\
\text { according to the respective } \\
\text { official tables (AfA). }\end{array}$ & $\begin{array}{l}\text { If (a) is given and (c) the } \\
\text { subsequent rent is less than } \\
\text { the usual depreciation rate } \\
\text { of the asset. }\end{array}$ & $\begin{array}{l}\text { If the lease is firm-specific, } \\
\text { i.e. it can only be used } \\
\text { by the lessee the asset has } \\
\text { to be capitalized regardless } \\
\text { of (a), (b) or (c). }\end{array}$ \\
\hline
\end{tabular}

Table 2: Compilation of hypotheses

\begin{tabular}{|c|c|c|c|}
\hline \multicolumn{2}{|c|}{ Hypothesis } & \multirow{2}{*}{ 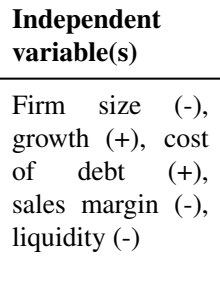 } & \multirow{2}{*}{$\begin{array}{l}\text { Expected sign } \\
\begin{array}{l}\text { See respective } \\
\text { variable }\end{array}\end{array}$} \\
\hline H1 & $\begin{array}{l}\text { The primary aim of this paper is to test the hypothesis put forth by } \\
\text { Eisfeld and Rampini (2009) that financially constrained firms lease a } \\
\text { greater share of their assets to mitigate problems of asymmetric infor- } \\
\text { mation. Since the degree of the financial constraint of a firm is not } \\
\text { directly observable we aim to proxy for it by using several indicator } \\
\text { variables. }\end{array}$ & & \\
\hline $\mathrm{H} 2$ & $\begin{array}{l}\text { The trade-off theory of capital structure views leases as substitutes for } \\
\text { secured debt. The theory predicts that leases and debt are substitutes } \\
\text { since a firm's marginal cost of new debt or new leases increases with } \\
\text { fixed claim obligations in place (Yan 2006). Hence, an increase in the } \\
\text { leverage of a firm should lead to a compensating decrease of the use of } \\
\text { leases. }\end{array}$ & Leverage & Negativ \\
\hline $\mathrm{H} 3$ & $\begin{array}{l}\text { The tax-arbitrage argument typically predicts that leasing participants } \\
\text { gain when the lessor's tax rate exceeds that of the lessee (Elayan, Meyer, } \\
\text { and Li 2006, Eisfeldt and Rampini 2009). In the German case, however, } \\
\text { there is only a single corporate tax rate and thus the arbitrage-argument } \\
\text { can not be applied. Yet an often made "selling argument" by lessors is } \\
\text { that the (fully deductible) leasing rate may be higher than the maximal } \\
\text { depreciation rate and thus help to reduce taxes in a given year (although } \\
\text { not on the whole). Based on the assumption that lessees in fact use } \\
\text { leases to reduce their tax burden in a given year we would expect a } \\
\text { positive relation between the taxrate and the lease ratio. }\end{array}$ & Tax rate & positiv \\
\hline
\end{tabular}


Table 3: Definitions of the main variables employed in the empirical tests

\begin{abstract}
Dependent variable
Lease ratio The lease ratio depicts a firm's dependency on leasing and is measured by total lease expenses over total assets. The dependent variable supports the idea that lease contracts can provide financing to creditconstrained firms due to their repossessing advantage of the financed asset in case of default.
\end{abstract}

\title{
Independent variables (firm characteristics)
}

Tax rate This is a measure of the average tax rate of the firm which is defined by tax expenses before financing costs divided by income before tax and financing costs (i.e. lease and interest expenses). To account for different taxation requirements of private German firms with no limited liability, an additional $25 / \%$ (the corporate tax rate for the observation period) of income before tax has been added to the tax expenses of those firms that are exempt from corporate taxes (Einzelunternehmen, OHG, Genossenschaft, KG, BGB) to ensure comparability.

Firm profitability Profitability is employed as a measure of economic performance and is defined as the ratio of income before taxes over total assets (ROA).

Firm size $\quad$ Firm size is depicted by the natural logarithm of total assets and is one of the most widely used proxies for the level of financial constraint (e.g. Devereux and Schiantarelli (1989); Oliner and Rudebusch (1992)). It accounts for different financing patterns of larger firms due to a better access to capital markets and cash-pooling agreements within the firm. Furthermore, large firms face less severe asymmetric information problems due to higher reporting requirements and analyst coverage and thus are less likely to be credit constraint.

Firm growth As proxy for growth firms the sales growth of actual to prior year is taken.

Liquidity The liquidity ratio is calculated by current assets over short-term liabilities and gives the degree by which short-term funds are covered by assets that can be liquidated within a short time. A ratio below $100 \%$ indicates illiquidity and thus increases the risk of default.

Sales margin The sales margin is obtained by dividing net profits by gross sales and reflects the profitability (and efficiency) of a business.

Cost of debt The average cost of debt of a firm is defined by interest expenses over total debt. In this regard a note of caution is in order because the data does not allow to account for different rates paid on long- and shortterm debt. However, an inspection of the relative proportion of longer and shorter liabilities of firms in our sample shows that this relation remains rather stable over different size classes and thus a potential distortion due to interest costs of different debt maturities should be reasonably low.

Leverage The leverage of a firm is depicted by total debt over total assets.

Control variables

Time fixed effects The time dummy accounts for effects that may influence all firms in a given year by the same amount. This facilitates the elimination of possible sources of spuriousness due to common trend in the observed variables.

Legal form The dummy variable differentiates seven legal forms of firms and accounts for differences in reporting and fiscal requirements. Smaller firms in which the owner's liability is not limited by his share often have legal forms such as "Einzelunternehmen" ( $\approx$ Sole trader) or "Offene Handelsgesellschaft $(\mathrm{OHG}) "(\approx$ General partnership) which have less reporting requirements and can therefore be considered more informationally opaque.

Capital intensity This variable is comprised by fixed assets over total assets. Since industry codes were not available for this study, the variables legal form and capital intensity are instated to control for the main industry effects. 


\section{Table 4: Firm characteristics of lessee firms and non-lessee firms}

Table 4 shows the median properties of all firms as well as features of lessee and non-lessee firms respectively. Our classification of the latter is relatively crude; a firm is counted as a non-lessee firm if it reports no lease expenses in the income statement and lessee firms vice versa.

Leverage is calculated as total debt over total assets. The cost of debt are obtained by dividing interest expenses by total debt liabilities, long-term debt (over 5 years maturity) is depicted as fraction of total loans and liquidity is calculated as current assets over short-term debt.

\begin{tabular}{|c|c|c|c|c|c|c|c|}
\hline Year & No. of obs. & $\begin{array}{l}\text { Percent. of } \\
\text { lessee firms }\end{array}$ & Leverage & $\begin{array}{l}\text { Total assets } \\
\text { in } €\end{array}$ & $\begin{array}{l}\text { Cost of } \\
\text { debt }\end{array}$ & $\begin{array}{l}\text { Long-term } \\
\text { debt }\end{array}$ & Liquidity \\
\hline 2002 & 26,436 & $40 \%$ & $80 \%$ & 780,922 & $5.1 \%$ & $12 \%$ & $111 \%$ \\
\hline 2003 & 30,361 & $43 \%$ & $78 \%$ & 763,485 & $5.0 \%$ & $11 \%$ & $114 \%$ \\
\hline 2004 & 31,804 & $45 \%$ & $77 \%$ & 749,236 & $4.7 \%$ & $10 \%$ & $115 \%$ \\
\hline 2005 & 31,734 & $47 \%$ & $75 \%$ & 777,000 & $4.4 \%$ & $9 \%$ & $117 \%$ \\
\hline 2006 & 27,041 & $51 \%$ & $72 \%$ & 896,857 & $4.3 \%$ & $9 \%$ & $125 \%$ \\
\hline Average & 147,376 & $45 \%$ & $76 \%$ & 793,500 & $4.7 \%$ & $10 \%$ & $116 \%$ \\
\hline Lessee firms & 62,257 & $100 \%$ & $77 \%$ & 857,442 & $4.6 \%$ & $9 \%$ & $116 \%$ \\
\hline Non-lessee firms & 85,119 & $0 \%$ & $70 \%$ & 751,037 & $4.8 \%$ & $11 \%$ & $117 \%$ \\
\hline
\end{tabular}

\section{Table 5: Description of firms using non-capitalized and capitalized finance leases}

Table 5 shows the percentage of firms using using non-capitalized (operating and finance) as well as capitalized finance leases and their respective properties. A firm is counted as non-capitalized lease firm if it reports lease expenses in the income statement but no finance lease liabilities on the balance sheet. A firm using capitalized finance leases, on the other hand, is classified in this group if it reports lease liabilities on the balance sheet.

\begin{tabular}{|c|c|c|c|c|c|c|c|}
\hline \multirow[b]{2}{*}{ Year } & \multirow[b]{2}{*}{ No. of obs. } & \multicolumn{3}{|c|}{ Firms using non-capitalized leases } & \multicolumn{3}{|c|}{ Firms using capitalized finance leases } \\
\hline & & Leverage & $\begin{array}{l}\text { Percent. of } \\
\text { lessee firms }\end{array}$ & $\begin{array}{l}\text { Cost } \\
\text { debt }\end{array}$ & Leverage & $\begin{array}{l}\text { Percent. of } \\
\text { lessee firms }\end{array}$ & $\begin{array}{l}\text { Cost of } \\
\text { debt }\end{array}$ \\
\hline 2002 & 2,191 & 0.76 & $91 \%$ & $4.9 \%$ & 0.73 & $9 \%$ & $5.0 \%$ \\
\hline 2003 & 3,097 & 0.74 & $91 \%$ & $4.7 \%$ & 0.68 & $9 \%$ & $4.7 \%$ \\
\hline 2004 & 4,576 & 0.72 & $90 \%$ & $4.5 \%$ & 0.63 & $10 \%$ & $4.2 \%$ \\
\hline 2005 & 5,194 & 0.72 & $90 \%$ & $4.2 \%$ & 0.64 & $10 \%$ & $3.8 \%$ \\
\hline 2006 & 5,384 & 0.69 & $89 \%$ & $4.1 \%$ & 0.61 & $11 \%$ & $3.8 \%$ \\
\hline Average & 20,442 & 0.73 & $90 \%$ & $4.5 \%$ & 0.66 & $10 \%$ & $4.3 \%$ \\
\hline
\end{tabular}

\section{Table 6: Lease and interest expense ratios of lessee firms by years}

Table 6 shows the ratio of total lease and interest expenses to total financing costs as well as the average interest rates of small and large firms

\begin{tabular}{|c|c|c|c|c|c|c|c|c|c|c|}
\hline & \multirow[b]{2}{*}{ Year } & \multirow[b]{2}{*}{ No. of obs. } & \multicolumn{2}{|c|}{ All firms } & \multicolumn{3}{|c|}{ 1st quartile (small) } & \multicolumn{3}{|c|}{ 4th quartile (large) } \\
\hline & & & Leases & Interest & Leases & Interest & $\begin{array}{l}\text { Cost of } \\
\text { debt }\end{array}$ & Leases & Interest & $\begin{array}{l}\text { Cost } \\
\text { debt }\end{array}$ \\
\hline \multirow{6}{*}{ respectively. } & 2002 & 2,191 & $37 \%$ & $63 \%$ & $49 \%$ & $51 \%$ & $5.5 \%$ & $29 \%$ & $71 \%$ & $4.5 \%$ \\
\hline & 2003 & 3,097 & $39 \%$ & $61 \%$ & $51 \%$ & $49 \%$ & $5.3 \%$ & $31 \%$ & $69 \%$ & $4.4 \%$ \\
\hline & 2004 & 4,576 & $41 \%$ & $59 \%$ & $53 \%$ & $47 \%$ & $5.1 \%$ & $33 \%$ & $67 \%$ & $4.2 \%$ \\
\hline & 2005 & 5,194 & $42 \%$ & $58 \%$ & $54 \%$ & $46 \%$ & $4.8 \%$ & $33 \%$ & $67 \%$ & $4.1 \%$ \\
\hline & 2006 & 5,384 & $43 \%$ & $57 \%$ & $54 \%$ & $46 \%$ & $4.8 \%$ & $34 \%$ & $66 \%$ & $3.8 \%$ \\
\hline & Average & 20,442 & $40 \%$ & $60 \%$ & $52 \%$ & $48 \%$ & $5.1 \%$ & $32 \%$ & $68 \%$ & $4.2 \%$ \\
\hline
\end{tabular}




\begin{tabular}{|c|c|c|c|c|c|c|c|c|c|c|c|}
\hline \multicolumn{12}{|c|}{ Table 7: Correlation matrix } \\
\hline 20,442 observations & 1 & 2 & 3 & 4 & 5 & 6 & 7 & 8 & 9 & 10 & 11 \\
\hline Lease ratio (1) & 1 & & & & & & & & & & \\
\hline Debt<1 year $(2)$ & $0.08^{*}$ & 1 & & & & & & & & & \\
\hline Debt>5 year $(3)$ & $-0.09 *$ & $-0.43^{*}$ & 1 & & & & & & & & \\
\hline Trade credit (4) & $0.06^{*}$ & $0.33^{*}$ & $-0.35^{*}$ & 1 & & & & & & & \\
\hline Cost of debt (5) & $0.06^{*}$ & $-0.23 *$ & $0.18^{*}$ & $-0.26^{*}$ & 1 & & & & & & \\
\hline Capital intensity (6) & $-0.05^{*}$ & $-0.42 *$ & $0.41 *$ & $-0.35^{*}$ & $0.15^{*}$ & 1 & & & & & \\
\hline Tax rate $(7)$ & $-0.13^{*}$ & $-0.15^{*}$ & $-0.10^{*}$ & $0.11 *$ & $-0.14 *$ & $-0.12 *$ & 1 & & & & \\
\hline Profitability (8) & $0.23^{*}$ & $-0.06^{*}$ & $-0.06^{*}$ & $0.03^{*}$ & $0.10^{*}$ & $-0.08^{*}$ & $0.37 *$ & 1 & & & \\
\hline Size $(9)$ & $-0.25 *$ & $-0.02 *$ & $-0.06^{*}$ & $0.01 *$ & $-0.13^{*}$ & $0.10^{*}$ & $-0.14^{*}$ & $-0.41^{*}$ & 1 & & \\
\hline Growth enterprise (10) & -0.00 & 0.00 & 0.00 & 0.00 & 0.00 & 0.01 & 0.00 & 0.00 & $0.02 *$ & 1 & \\
\hline Liquidity (11) & $-0.04 *$ & $-0.38^{*}$ & $-0.02 *$ & 0.00 & $0.08 *$ & $-0.12 *$ & $0.15^{*}$ & $0.06^{*}$ & $0.04 *$ & 0.00 & 1 \\
\hline
\end{tabular}

\section{Table 8: Fixed effects linear panel data models}

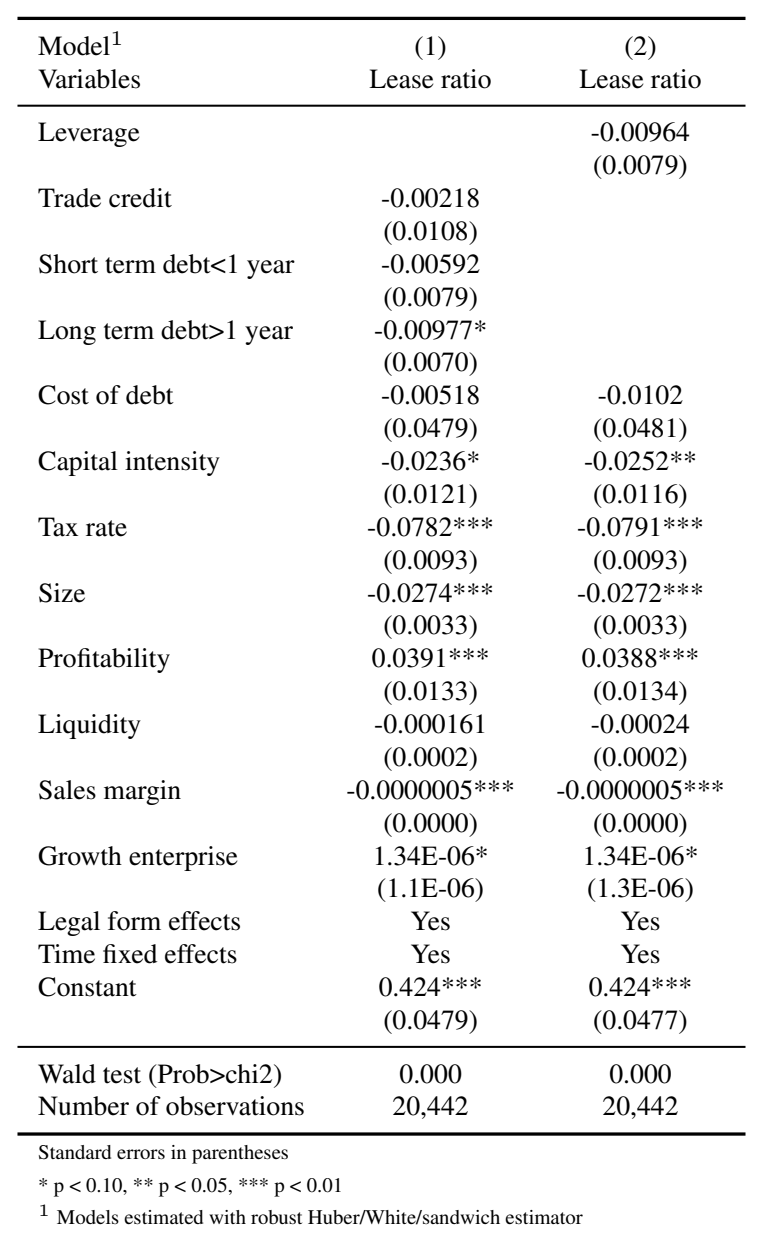


Table 9: 2-step GMM model

\begin{tabular}{|c|c|c|c|}
\hline \multirow{2}{*}{$\begin{array}{l}\text { Model }^{1} \\
\text { Variables }^{-}\end{array}$} & \multirow{2}{*}{$\begin{array}{c}\text { Lease ratio } \\
-0.0951^{* * *} \\
(0.0328)\end{array}$} & \multicolumn{2}{|l|}{$(\star)$ Legal forms } \\
\hline & & Einzelfirma & $\begin{array}{l}0.0339 * * * \\
(0.0104)\end{array}$ \\
\hline Cost of debt & $\begin{array}{c}0.291^{*} \\
(0.1630)\end{array}$ & BGB-Gesellschaft & $\begin{array}{l}0.0481 * * * \\
(0.0101)\end{array}$ \\
\hline Capital intensity & $\begin{array}{c}-0.0807 * * \\
(0.0408)\end{array}$ & OHG & $\begin{array}{l}0.0388^{* * *} \\
(0.0104)\end{array}$ \\
\hline Tax rate & $\begin{array}{c}-0.0958^{* * * *} \\
(0.0139)\end{array}$ & KG & $\begin{array}{l}0.0267 * * * \\
(0.0098)\end{array}$ \\
\hline Profitability & $\begin{array}{c}0.0256^{* * *} \\
(0.0124)\end{array}$ & $\mathrm{GmbH}$ & $\begin{array}{l}0.00474 \\
(0.0049)\end{array}$ \\
\hline Firm size & $\begin{array}{c}-0.0160 * * * \\
(0.0057)\end{array}$ & GmbH \& Co. KG & $\begin{array}{l}0.00413 \\
(0.0043)\end{array}$ \\
\hline Liquidity & $\begin{array}{c}-0.00154 * * \\
(0.0007)\end{array}$ & AG & $\begin{array}{l}-0.00689 \\
(0.0104)\end{array}$ \\
\hline Sales margin & $\begin{array}{c}-0.000002^{* * * *} \\
(-6.66 \mathrm{E}-07)\end{array}$ & & \\
\hline Growth enterprise & $\begin{array}{c}0.0000009 * * \\
(-4.51 \mathrm{E}-07)\end{array}$ & & \\
\hline Legal form effects $(\star)$ & Yes & & \\
\hline Time fixed effects & Yes & & \\
\hline Underidentification test & 0.000 & & \\
\hline Weak identification test ${ }^{2}$ & $5.41 *$ & & \\
\hline Overidentification test & 0.95 & & \\
\hline Number of observations & 10,497 & & \\
\hline \multicolumn{4}{|c|}{$\begin{array}{l}{ }^{2} \text { Critical values for the Stock and Yogo }(2005) \text { weak-instrument test (5-percent significance) based on TSLS size } \\
\text { with exact identification are } 12.20,7.77,5.35 \text { and } 4.40 \text { for the } 5 \text {-percent, } 10 \text {-percent, } 20 \text {-percent, 30-percent sizes, } \\
\text { respectively. } * * * \text { means that the weak instruments hypothesis is rejected with the most stringent criterion, } * * \text { means the } \\
\text { null is rejected with the second criterion, and } * \text { that it is rejected with the third criterion. }\end{array}$} \\
\hline
\end{tabular}




\section{References}

Adedeji, A., And R. C. Stapleton (1996): “Leases, Debt and Taxable Capacity,” Applied Financial Economics, 6(1), 71-83.

Ang, J., ANd P. P. Peterson (1984): “The Leasing Puzzle,” Journal of Finance, 39(4), 105565.

BAUM, C. F. (2000): "XTTEST3: Stata module to compute Modified Wald statistic for groupwise heteroskedasticity," Statistical Software Components, Boston College Department of Economics.

BAUM, C. F. (2006): An Introduction to Modern Econometrics Using Stata. STATA Press.

BAUM, C. F., AND M. E. Schaffer (2007): "Enhanced routines for instrumental variables/GMM estimation and testing," Discussion paper, Boston College Economics Working Paper No. 667.

Baum, C. F., M. E. Schaffer, and S. Stillman (2003): "Instrumental variables and GMM: Estimation and testing," Stata Journal, 3(1), 1-31.

Baum, C. F., M. E. Schaffer, and S. Stillman (2007): “ivreg2: Stata module for extended instrumental variables/2SLS, GMM and AC/HAC, LIML, and k-class regression.," Boston College Department of Economics, Statistical Software Components S425401.

Beattie, V., A. Goodacre, And S. Thomson (2000): "Operating leases and the assessment of lease-debt substitutability," Journal of Banking \& Finance, 24(3), 427-470.

Bharath, S. T., P. Pasquariello, and G. Wu (2006): "Does Asymmetric Information Drive Capital Structure Decisions?," SSRN eLibrary.

Deloof, M., I. LAGAert, And I. Verschueren (2007): "Leases and Debt: Complements or Substitutes? Evidence from Belgian SMEs,” Journal of Small Business Management, Vol. 45, No. 4, 491-500.

Devereux, M., and F. Schiantarelli (1989): "Investment, Financial Factors and Cash Flow: Evidence From UK Panel Data," NBER Working Papers 3116, National Bureau of Economic Research, Inc. 
Eisfeldt, A., AND A. RAMPINI (2009): "Leasing, Ability to Repossess, and Debt Capacity," Review of Financial Studies, 22(4), 1621-1657.

Elayan, F. A., T. O. Meyer, and J. Li (2006): "Evidence from Tax-Exempt Firms on Motives for Participating in Sale-Leaseback Agreements," Journal of Real Estate Research, 28(4), 381-410.

Greene, W. (2000): Econometric Analysis. Upper Saddle River, NJ: Prentice-Hall.

Hackethal, A., And R. H. Schmidt (2004): "Financing Patterns: Measurement Concepts and Empirical Results," Working Paper Series: Finance and Accounting 125, Department of Finance, Goethe University Frankfurt am Main.

Hansen, L. P. (1982): "Large Sample Properties of Generalized Method of Moments Estimators," Econometrica, 50(4), 1029-54.

HARRIS, M., AND A. RAVIV (1991): “The Theory of Capital Structure,” Journal of Finance, 46(1), 297-355.

Hart, O., AND J. Moore (1995): "A Theory of Debt Based on the Inalienability of Human Capital,” NBER Working Papers 3906, National Bureau of Economic Research, Inc.

KFW (2007): "Mittelstandmonitor 2007, Den Aufschwung festigen - Beschäftigung und Investitionen weiter vorantreiben," Discussion paper, KfW Bankengruppe, Abteilung Volkswirtschaft.

(2008): Unternehmensbefragung 2008.

Krishnan, V. S., And R. C. MOYER (1994): "Bankruptcy Costs and the Financial Leasing Decision," Financial Management, 23(2).

McConnell, J. J., ANd J. S. Schallheim (1983): "Valuation of asset leasing contracts," Journal of Financial Economics, 12(2), 237-261.

Miwa, Y., And J. M. RAMSEYeR (2005): “Trade Credit, Bank Loans, and Monitoring: Evidence from Japan,” CIRJE F-Series CIRJE-F-381, CIRJE, Faculty of Economics, University of Tokyo. 
MolinA, C. A. (2005): “Are Firms Underleveraged? An Examination of the Effect of Leverage on Default Probabilities," Journal of Finance, 60(3), 1427-1459.

MYERS, S. C. (1976): “Determinants of corporate borrowing,” Working papers 875-76., Massachusetts Institute of Technology (MIT), Sloan School of Management.

Newey, W., And K. West (1987): “A Simple, Positive Semi-Definite, Heteroscedastic and Autocorrelation Consistent Covariance Matrix," Econometric, 55, p. 703-708.

Oliner, S. D., And G. D. Rudebusch (1992): "Sources of the Financing Hierarchy for Business Investment," The Review of Economics and Statistics, 74(4), 643-54.

Petersen, M. A., And R. G. Rajan (1994): “The Benefits of Lending Relationships: Evidence from Small Business Data," Journal of Finance, 49(1), 3-37.

(1995): “The Effect of Credit Market Competition on Lending Relationships," The Quarterly Journal of Economics, pp. 407-443.

SCHAFFER, M. E. (2005): "XTIVREG2: Stata module to perform extended IV/2SLS, GMM and AC/HAC, LIML and k-class regression for panel data models," Statistical Software Components, Boston College Department of Economics.

Sharpe, S. A., And H. H. NGUYen (1995): "Capital market imperfections and the incentive to lease," Journal of Financial Economics, 39(2-3), 271-294.

Smith, J. K. (1992): Trade Credit. The New Palgrave Dictionary of Money \& Finance, London: Macmillan.

Stock, J. H., And M. Yogo (2005): Testing for weak instruments in linear IV regression, Identification and Inference for Econometric Models: Essays in Honor of Thomas Rothenberg. Cambridge: Cambridge University Press.

StUlz, R., AND H. JOHNSON (1985): “An analysis of secured debt,” Journal of Financial Economics, 14(4), 501-521.

TNS INFRATEST, F. (2007): "Leasing in Deutschland 2007,” .

Wooldridge, J. M. (2002): Econometric Analysis of Cross Section and Panel Data. Cambridge, MA: MIT Press. 
YAN, A. (2006): "Leasing and Debt Financing: Substitutes or Complements?," Journal of Financial and Quantitative Analysis, 41(3), 709-731. 